\title{
Stress cardiomyopathy misinterpreted as ST-segment elevation myocardial infarction in a patient with aneurysmal subarachnoid hemorrhage: a case report
}

\author{
IULIAN ENACHE ${ }^{1}$, RĂZVAN ALEXANDRU RADU ${ }^{1,3}$, ELENA OANA TERECOAS $\breve{~}^{1,3}$, \\ BOGDAN DOROBĂȚ ${ }^{2}$, CRISTINA TIU ${ }^{1,3}$ \\ ${ }^{1}$ Department of Neurology, University Emergency Hospital Bucharest \\ ${ }^{2}$ Department of Radiology and Medical Imaging, University Emergency Hospital Bucharest \\ 3 "Carol Davila" University of Medicine and Pharmacy
}

\begin{abstract}
Cardiac abnormalities are frequently reported in acute subarachnoid hemorrhage $(\mathrm{SAH})$ patients. However, frank ST-elevation and myocardial dysfunction mimicking acute coronary syndrome is a rare occurrence. Systemic and local catecholamine release mediate myocardial injury and may explain raised troponin levels, concordant regional wall motion abnormalities and systolic dysfunction. These findings can pose a significant problem in the acute setting where "time-is-muscle" paradigm can rush clinicians towards a "rule-in" diagnosis of acute myocardial infarction.

We present the case of a 60 -year-old male who arrived at a regional emergency department with loss of consciousness, chest pain and headache. His ECG showed ST-elevation in precordial leads with corresponding region wall motion abnormalities and dynamically elevated troponin levels which supported a diagnosis of acute myocardial infarction. Percutaneous coronary intervention was attempted but found no hemodynamically significant lesions and the patient was managed conservatively with antithrombotic treatment. Further work-up for his headache led to the diagnosis of aneurysmal SAH and subsequent endovascular coiling. The patient was discharged with a good clinical outcome. We discuss the potential catastrophic consequences of interpreting neurologic myocardial stunning as STEMI. Use of potent antithrombotic therapies, like bridging thrombolysis, in this setting can lead to dismal consequences. Clinical history should still be carefully obtained in the acute setting in this era of sensitive biomarkers.
\end{abstract}

Key words: subarachnoid hemorrhage, myocardial stunning, st elevation myocardial infarction, stress cardiomyopathy, takotsubo cardiomyopathy.

\section{INTRODUCTION}

Cardiac abnormalities are frequently encountered in subarachnoid hemorrhage (SAH), transitory electrocardiographic (ECG) changes being found in up to $92 \%$ of SAH patients [1]. T-wave inversion, U waves, QT-interval prolongation, ST-segment depression are frequent findings in this setting, as opposed to abnormal Q-waves and ST-segment elevation [2, 3]. The ECG changes may be accompanied by transient regional wall motion abnormalities (RWMA) and raised cardiac troponin (cTn) levels and have been referred to as "neurogenic cardiac stunning", "neurogenic stress cardiomyopathy" (NSC), "neurogenic stunned myocardium" (NSM) or "Takotsubo cardiomyopathy" (TC) $[4,5]$.

Misdiagnosis of SAH-associated stress cardiomyopathy as acute myocardial infarction (MI) might lead to incorrect therapeutic decisions including potent antithrombotic therapy with unfortunate consequences in SAH patients. We report the case of a 60 -year-old man admitted and initially treated for ST-elevation myocardial infarction (STEMI) who was subsequently diagnosed with $\mathrm{SAH}$ and stress cardiomyopathy.

\section{CASE REPORT}

A 60-year-old Caucasian male was admitted to a regional emergency department following a sudden loss of consciousness (LOC) with subsequent collapse. His family reported that immediately after killing a pig, as it is customary in the rural areas of our country during Christmas times, he grabbed his head, fell down from approximately 1.5 meters height and became unresponsive. He progressively recovered his consciousness approximately thirty minutes later and complained of severe headache and chest pain, which he described as worsening with movements and deep breathing. He smoked 40-packs/year, was previously diagnosed with dyslipidemia and took no medication at home. Physical examination was unremarkable, except for 
a small superficial forehead excoriation. Ancillary test results are presented in Table 1. High-sensitivity cardiac troponin-I value detected at 4 hours after onset was $750 \mathrm{ng} / \mathrm{L}$ and $1999 \mathrm{ng} / \mathrm{L}$ at 6.5 hours. His initial ECG showed $0.2 \mathrm{mV}$ ST-segment elevation in V2-V4 leads and negative T-waves in inferior and lateral limb leads (Figure 1A). Transthoracic echocardiography revealed left ventricular global systolic hypokinesia [ejection fraction (EF) of 35\%] with apical and inferior septum akinesia.

Table 1

Blood analysis at admission

\begin{tabular}{|c|c|c|}
\hline Test & Result & Reference range \\
\hline White blood cells & 11.3 & {$\left[3.6-10.2 \times 10^{3} / \mu \mathrm{L}\right]$} \\
\hline Red blood cells & 4.94 & {$\left[4.06-5.63 \times 10^{6} / \mu \mathrm{L}\right]$} \\
\hline Hemoglobin & 13.5 & {$[12.5-16.3 \mathrm{~g} / \mathrm{dL}]$} \\
\hline Hematocrit & 40.9 & {$[36.7-47.1 \%]$} \\
\hline Platelet count & 210 & {$\left[152-348 \times 10^{3} / \mu \mathrm{L}\right]$} \\
\hline Glycemia & 125 & {$[70-110 \mathrm{mg} / \mathrm{dL}]$} \\
\hline ALT* $^{*}$ & 56 & {$[<40 \mathrm{U} / \mathrm{L}]$} \\
\hline AST $^{*}$ & 46 & {$[<42 \mathrm{U} / \mathrm{L}]$} \\
\hline GGT $^{*}$ & 14 & {$[<75 \mathrm{U} / \mathrm{L}]$} \\
\hline BUN* & 17.4 & {$[0.0-23.0 \mathrm{mg} / \mathrm{dL}]$} \\
\hline Creatinine & 1.0 & {$[135-145 \mathrm{mg} / \mathrm{dL}]$} \\
\hline Sodium & 140 & {$[3.5-5.1 \mathrm{mEq} / \mathrm{L}]$} \\
\hline Potassium & 4.1 & $-[\mu \mathrm{g} / \mathrm{mL}]$ \\
\hline D-dimer & $>5.00$ & {$[<29.0 \mathrm{ng} / \mathrm{L}]$} \\
\hline hs-cTnI* $-4 h$ & 759 & {$[<29.0 \mathrm{ng} / \mathrm{L}]$} \\
\hline hs-cTnI* $-6 h$ & 1999 & $-[\mathrm{pg} / \mathrm{mL}]$ \\
\hline NT-proBNP* & 204 & $\mathrm{G}$ \\
\hline
\end{tabular}

*ALT - alanine aminotransferase, AST - aspartate aminotransferase, BUN - blood urea nitrogen, GGT - gamma-glutamyltransferase, hs-cTnI - high sensitivity cardiac troponin I, NT-proBNP - N-terminal pro-brain natriuretic peptide.

Raised D-dimer levels and atypical chest pain prompted a search for pulmonary embolism which was ruled out by contrast-enhanced CT. His headache complaint was overshadowed by cardiac troponin dynamics, ECG changes and echocardiography findings and the patient was initially diagnosed with STEMI.

The patient was transferred to our hospital 8 hours after symptoms onset for primary percutaneous coronary intervention (PCI). Coronarography revealed two hemodynamically non-significant stenoses in the middle segment of the left circumflex artery (Figure 1B) and triple antithrombotic therapy was initiated with loading doses of ticagrelor, aspirin and enoxaparin. ST-segment elevation gradually disappeared within the first 12 hours (Figure 1C), but 48 hours after chest pain onset he developed deep T-wave inversions in leads V3-V6 which persisted during the entire hospitalization.

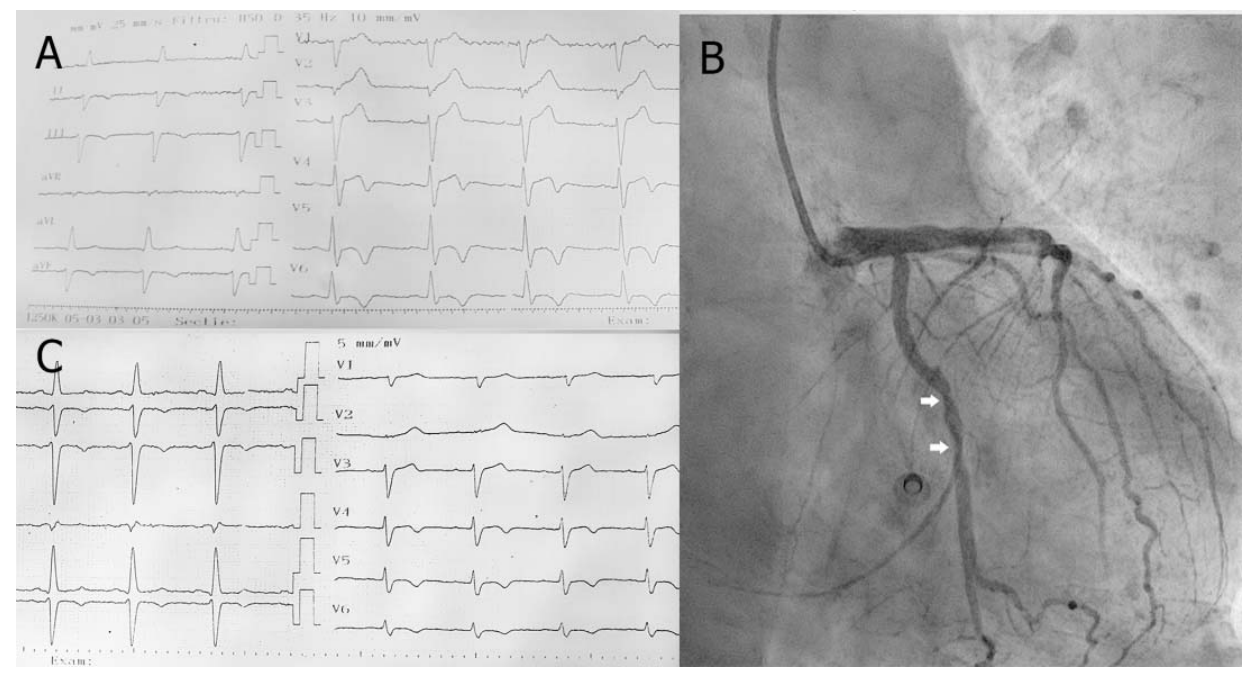

Figure 1. (A) Admission ECG showing sinus rhythm, $0.2 \mathrm{mV} \mathrm{ST-segment} \mathrm{elevation} \mathrm{in} \mathrm{leads} \mathrm{V2-V4} \mathrm{and} \mathrm{negative} \mathrm{T-waves} \mathrm{in} \mathrm{leads}$ DII, DIII, aVF, V5 and V6; (B) Coronary angiography showing 2 serial stenoses of 50\% in the middle segment of the left circumflex artery (arrows); (C) ECG obtained $12 \mathrm{~h}$ after admission showing resolution of ST-elevation with persistence of negative T-waves. 
The patient continued to complain of persistent severe headache. Twenty-four hours after admission, neurologic examination showed neck stiffness and a brain CT scan was performed revealing bilateral fronto-temporo-parietal SAH (Figure 2A). Triple antithrombotic therapy was stopped and the patient was referred to cerebral angiography. A saccular aneurysm was identified at the bifurcation of the left middle cerebral artery (Figure 2B) and was subsequently treated with endovascular coiling (Figure 2C).

The patient was discharged one week later without any disability. Follow-up echocardiography at discharge showed normal cardiac function without wall motion abnormalities.
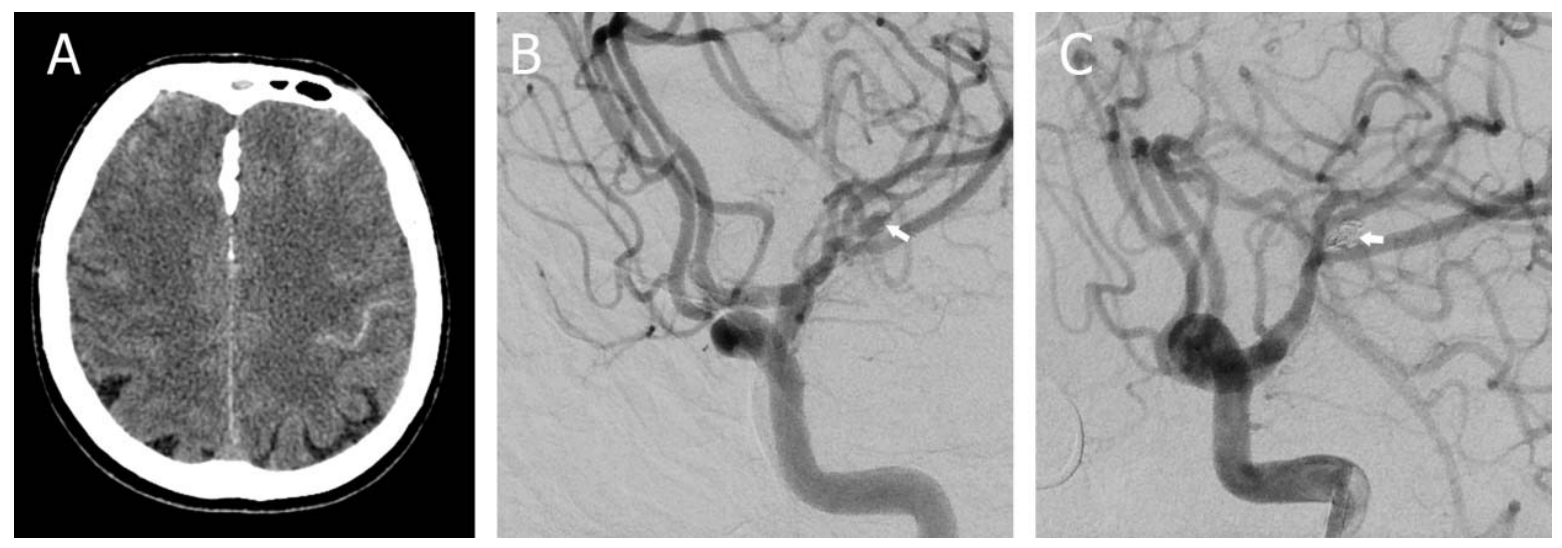

Figure 2. A) Native brain CT scan showing diffuse subarachnoid hemorrhage; (B) Cerebral angiography showing a saccular aneurysm with narrow neck (arrow) at the origin of the superior M2-segment of the left middle cerebral artery;

(C) Obliterated aneurysm after endovascular coiling (arrow).

\section{DISCUSSION}

We present the case of a patient initially admitted to a regional emergency department with non-syncopal transient LOC. The high troponin value together with the electrocardiographic and echocardiographic findings were suggestive for an acute MI and the patient was referred to a tertiary center for primary PCI. However, his protracted LOC and severe headache should have raised concern for a primary or at least co-occurring neurologic event [6].

LOC is the presenting feature in $40 \%$ of $\mathrm{SAH}$ patients, being more frequently encountered in those patients who also develop accompanying cardiac dysfunction [7]. Moreover, SAH patients presenting with LOC, more rarely report having thunderclap headache at onset [7]. LOC is presumably caused by an abrupt increase in intracranial pressure with secondary brain perfusion failure which may be further worsened by a potential $\mathrm{SAH}$-associated cardiac dysfunction [8].

Excess systemic catecholamine release in $\mathrm{SAH}$ patients might mediate coronary vasospasm and microvascular dysfunction leading to myocardial injury and stress cardiomyopathy $[9,10]$. The histopathologic hallmark of neurogenic cardiac injury characterized by contraction-band necrosis is different from localized myocardial necrosis produced by coronary obstruction $[5,11]$. The non-obstructed coronary arteries, the initial clinical picture and the proven aneurysmal SAH along with the reversibility of cardiac dysfunction retrospectively sustain that the most probable cause of the initial cardiac abnormalities was a stress cardiomyopathy, either NSM or TC. However, excluding a myocardial infarction with non-obstructed coronary artery is based on clinical rationale and to some extent a microvascular dysfunction could also contribute to stress cardiomyopathy [12].

Formal diagnostic criteria for NSM, referred to as an atypical variant of stress cardiomyopathy, have not been formulated yet [13]. There is no consensus whether NSM and TC are distinct entities or part of the same spectrum of catecholamine induced cardiac dysfunction [14-16]. ST-segment elevation is more frequently observed along with TC as opposed to NSM, mainly as a result of apical involvement with typical apical-ballooning aspect on echocardiography $[15,16]$. The various patterns of wall motion abnormality can probably be explained by the distribution of adrenergic receptors within the myocardium [15]. However, coronary obstruction remains the most important differential diagnosis in this setting as ECG and echocardiography findings are not specific for NSM or TC $[13,17]$.

Bulsara et al. proposed a set of criteria to help distinguish MI from reversible stunned myocardium in SAH patients, with the aim of selecting those patients which could safely undergo neurosurgery 
[18]. However, performance of troponin levels and electrocardiographic findings in distinguishing between stress cardiomyopathy and acute MI is low and coronary angiography should be performed to rule "in" or "out" a MI due to an obstructed coronary artery [19]. The presence of certain acute neurological diseases might be a helpful indicator of stress cardiomyopathy as the prevalence of neurological disorders is twice as high in patients with TC as compared to patients with ACS. The InterTAK score can be also used to estimate the probability of TC in the emergency room [20].

Distinguishing between stress cardiomyopathy and STEMI in the setting of SAH is of utmost importance as the risk of intracerebral hemorrhage (ICH) is universally increased by antithrombotic therapy. Furthermore, iatrogenic ICH risk is higher in patients treated with glycoprotein IIb/IIIa inhibitors, thrombolytic agents and triple therapy and these agents should definitely be avoided in patients with unsecured ruptured intracerebral aneurysms until the aneurysm is secured [21, 22].

\section{CONCLUSION}

Headache and protracted loss of consciousness in patients with clinical, biological and electrophysiological findings suggestive of acute myocardial infarction should not be disregarded, as they may be the expression of different neurological disorders associated with stress cardiomyopathy.

Pacienții cu hemoragie subarahnoidiană (HSA) prezintă frecvent afectare cardiacă ce poate consta, în cazuri rare, în tulburare de cinetică parietală și supradenivelare de segment $S T$, modificări ce survin şi în cazul unui infarct miocardic acut. Disfuncția miocardică din hemoragia subarahnoidiană evidențiată prin tulburări electrocardiografice, de cinetică parietală și eventual dinamică enzimatică este probabil mediată de eliberare de catecolamine, atât sistemic cât și local. Aceste modificări pot crea dificultăți diagnostice în faza acută, în care sub auspiciul paradigmei "time - is - muscle" aceste modificări pot fi interpretate greșit ca infarct miocardic cu supradenivelare de segment $S T$.

Prezentăm cazul unui pacient de 60 de ani care s-a prezentat la un spital regional pentru pierderea stării de conștiență, cefalee și durere toracică. Electrocardiograma efectuată la prezentare a pus în evidență supradenivelare de segment ST însoțită de tulburări de cinetică parietală și dinamică enzimatică. S-a stabilit diagnosticul de infarct miocardic acut și pacientul a fost îndrumat spre coronarografie. Aceasta nu a pus însă în evidență leziuni semnificative hemodinamic și s-a decis tratament conservator antitrombotic. Ulterior, din cauza persistenței cefaleei, s-a efectuat o tomografie computerizată cerebrală care a pus în evidență hemoragie subarachnoidiană anevrismală. Anevrismul a fost securizat pe cale endovasculară, iar evoluția pacientului a fost favorabilă. Chiar dacă practica clinică actuală se bazează din ce in ce mai mult pe biomarkeri sensibili ce pot orienta rapid către o anumită patologie, acest caz subliniază importanța analizei minuțioase a tuturor datelor de anamneză pentru stabilirea unui diagnostic corect. Interpretarea greșită a disfuncției cardiace asociate HSA drept infarct miocardic acut poate avea consecințe dezastruoase prin administrarea de antitrombotice potente şi temporizarea securizării unui anevrism rupt.

Correspondence to: Răzvan Alexandru Radu, MD, Department of Neurology, University Emergency Hospital Bucharest, 169 Splaiul Independenței Street, Sector 5, 050098 Bucharest, Romania

Telephone: 0040728995201

E-mail: raduarazvan@yahoo.com

Acknowledgements: We hereby thank the patient, his family and our colleagues from the Cardiology Department of the University Emergency Hospital Bucharest.

Conflict of interest disclosure: The authors declare no conflict of interest. 


\section{REFERENCES}

1. WARTENBERG KE, MAYER SA. Medical Complications After Subarachnoid Hemorrhage. Neurosurg Clin N Am. 2010; 21(2):325-38.

2. ARONOW WS. Neurogenic stress cardiomyopathy associated with subarachnoid hemorrhage. Future Cardiol. $2015 ; 11(1): 77-87$.

3. HUANG CC, HUANG CH, KUO HY, CHAN CM, CHEN JH, CHEN WL. The 12-lead electrocardiogram in patients with subarachnoid hemorrhage: Early risk prognostication. Am J Emerg Med. 2012; 30(5):732-6.

4. MANSELLA G, JEGER R, BINGISSER R, NICKEL C. The Neurocardiogenic Spectrum in Subarachnoid Hemorrhage: A Case Report and Review of the Literature. Clin Pract Cases Emerg Med. 2017; 1(1):16-21.

5. BISO S, WONGRAKPANICH S, AGRAWAL A, YADLAPATI S, KISHLYANSKY M, FIGUEREDO V. A Review of Neurogenic Stunned Myocardium. Cardiovasc Psychiatry Neurol. 2017; 2017.

6. BRIGNOLE M, MOYA A, DE LANGE FJ, DEHARO JC, ELLIOTT PM, FANCIULLI A, et al. 2018 ESC Guidelines for the diagnosis and management of syncope. Eur Heart J. 2018; 39(21):1883-948.

7. SUWATCHARANGKOON S, MEYERS E, FALO C, SCHMIDT JM, AGARWAL S, CLAASSEN J, et al. Loss of consciousness at onset of subarachnoid hemorrhage as an important marker of early brain injury. JAMA Neurol. 2016; 73(1):28-35.

8. CREMERS CHP, VAN DER BILT IAC, VAN DER SCHAAF IC, VERGOUWEN MDI, DANKBAAR JW, CRAMER MJ, et al. Relationship Between Cardiac Dysfunction and Cerebral Perfusion in Patients with Aneurysmal Subarachnoid Hemorrhage. Neurocrit Care. 2016; 24(2):202-6.

9. KERRO A, WOODS T, CHANG JJ. Neurogenic stunned myocardium in subarachnoid hemorrhage. J Crit Care. $2017 ;$ 38:27-34.

10. GHADRI JR, WITTSTEIN IS, PRASAD A, SHARKEY S, DOTE K, AKASHI YJ, et al. International Expert Consensus Document on Takotsubo Syndrome (Part I): Clinical Characteristics, Diagnostic Criteria, and Pathophysiology. Eur Heart J. 2018; 39(22):2032-46.

11. KRISHNAMOORTHY V, BURKHARD MACKENSEN G, GIBBONS EF, VAVILALA MS. Cardiac dysfunction after neurologic injury what do we know and where are we going? Chest. 2016; 149(5):1325-31.

12. TAMIS-HOLLAND JE, JNEID H, REYNOLDS HR, AGEWALL S, BRILAKIS ES, BROWN TM, et al. Contemporary Diagnosis and Management of Patients With Myocardial Infarction in the Absence of Obstructive Coronary Artery Disease: A Scientific Statement From the American Heart Association. Circulation. 2019; 139(18):E891-908.

13. KENIGSBERG BB, BARNETT CF, MAI JC, CHANG JJ. Neurogenic Stunned Myocardium in Severe Neurological Injury. Curr Neurol Neurosci Rep. 2019; 19(11).

14. ANCONA F, BERTOLDI LF, RUGGIERI F, CERRI M, MAGNONI M, BERETTA L, et al. Takotsubo cardiomyopathy and neurogenic stunned myocardium: Similar albeit different. Eur Heart J. 2016; 37(37):2830-2.

15. GUGLIN M, NOVOTOROVA I. Neurogenic Stunned Myocardium and Takotsubo Cardiomyopathy Are the Same Syndrome: A Pooled Analysis. Congest Hear Fail. 2011; 17(3):127-32.

16. WYBRANIEC M, MIZIA-STEC K, KRZYCH Ł. Neurocardiogenic injury in subarachnoid hemorrhage: A wide spectrum of catecholamin-mediated brain-heart interactions. Cardiol J. 2014; 21(3):220-8.

17. MEDINA DE CHAZAL H, DEL BUONO MG, KEYSER-MARCUS L, MA L, MOELLER FG, BERROCAL D, et al. Stress Cardiomyopathy Diagnosis and Treatment: JACC State-of-the-Art Review. J Am Coll Cardiol. 2018; 72(16):1955-71.

18. BULSARA KR, MCGIRT MJ, LIAO L, VILLAVICENCIO AT, BOREL C, ALEXANDER MJ, et al. Use of the peak troponin value to differentiate myocardial infarction from reversible neurogenic left ventricular dysfunction associated with aneurysmal subarachnoid hemorrhage. J Neurosurg. 2003; 98(3):524-8.

19. TEMPLIN C, GHADRI JR, DIEKMANN J, NAPP LC, BATAIOSU DR, JAGUSZEWSKI M, et al. Clinical features and outcomes of takotsubo (stress) cardiomyopathy. N Engl J Med. 2015; 373(10):929-38.

20. GHADRI JR, CAMMANN VL, JURISIC S, SEIFERT B, NAPP LC, DIEKMANN J, et al. A novel clinical score (InterTAK Diagnostic Score) to differentiate takotsubo syndrome from acute coronary syndrome: results from the International Takotsubo Registry. Eur J Heart Fail. 2017; 19(8):1036-42.

21. KWOK CS, KONTOPANTELIS E, MYINT PK, ZAMAN A, BERRY C, KEAVNEY B, et al. Stroke following percutaneous coronary intervention: Type-specific incidence, outcomes and determinants seen by the British Cardiovascular Intervention Society 2007-12. Eur Heart J. 2015; 36(25):1618-28.

22. POTTEGÅRD A, RODRÍGUEZ LAG, POULSEN FR, HALLAS J, GAIST D. Antithrombotic drugs and subarachnoid haemorrhage risk: A nationwide case-control study in Denmark. Thromb Haemost. 2015; 114(5):1064-75.

Received $16^{\text {th }}$ March 2020 